\title{
Cressa cretica L. growing in Egypt: Phytochemical study and potential antioxidant and hepato-protective activities
}

\author{
Taha S. El-Alfy ${ }^{1}$, Nagwa M. Ammar ${ }^{2}$, Sahar Y Al-Okbi ${ }^{3 *}$, Maha M Salama ${ }^{1}$, Hanan F. Aly ${ }^{4}$, Asmaa A Amer ${ }^{2}$ \\ ${ }^{1}$ Department of Pharmacognosy, Faculty of Pharmacy, Cairo University, Cairo, Egypt. \\ ${ }^{2}$ Department of Pharmacognosy, National Research Centre, Cairo, Egypt. \\ ${ }^{3}$ Nutrition and Food Sciences Department, National Research Centre, Cairo Egypt. \\ ${ }^{4}$ Department of Therapeutic Chemistry, National Research Centre, Cairo, Egypt.
}

\begin{tabular}{l}
\hline ARTICLE INFO \\
\hline Received on: $30 / 07 / 2018$ \\
Accepted on: $24 / 09 / 2018$ \\
Available online: 07/03/2019
\end{tabular}

Key words:

Cressa cretica L., bioactive fractions, hepatotoxicity, antioxidant activity.

\begin{abstract}
The present research was conducted to study the phytochemical constituents of the successive extracts of aerial parts of Cressa cretica L. and their antioxidant and hepatoprotective activities. Phenolic and flavonoid contents and their respective compounds were determined in ethyl acetate and $70 \%$ ethanol extract using chromatographic and spectral analyses. Unsaponifiable matter (USM) and fatty acids were investigated in the lipoidal matter by gas chromatography-mass spectrometry analysis. In vitro 2,2-diphenyl-1-picryl-hydrazyl radical scavenging activity and safety of successive extracts were assessed. The hepatoprotective effect of the safest extracts was evaluated in CCl4 intoxicated rats. Results showed that total phenolic contents were 21.07 and $22.95 \mathrm{mg}$ Gallic aid equivalent/g in ethyl acetate and $70 \%$ ethanol extract, respectively, while total flavonoid contents were 6.25 and $10.18 \mathrm{mg}$ catechin equivalent/g, respectively. Catechin and chlorogenic acid were the major phenolic compounds in ethyl acetate and ethanol extract, while rutin and apigenin-7-glucoside were the predominant flavonoids, respectively. Phytol was the major compound in USM, while 14-methyl-pentadecanoic acid was the predominant fatty acid. The most promising antioxidant was $70 \%$ ethanol extract. Ethyl acetate, $70 \%$ ethanol, and petroleum ether extracts showed complete safety and produced a hepatoprotective effect; ethyl acetate and $70 \%$ ethanol extracts were superior and comparable to silymarin and even more potent concerning specific biomarkers and histopathology.
\end{abstract}

\section{INTRODUCTION}

Convolvulaceae (morning glory family) is a large family comprising approximately 56 genera and about 1,600-1,700 species with a wide distribution in tropical and temperate regions of both hemispheres (Mabberley, 1997). In Egyptian flora, the family comprises 48 species (Boulos, 2009). Cressa is an example of herbaceous genera belonging to this family. Cressa cretica $\mathrm{L}$. (Convolvulaceae) is a perennial erect, small, dwarf shrub, or herb up to $38 \mathrm{~cm}$ height and much branched (Täckholm, 1974). It is commonly known in indigenous medicine in India as Rudravanti (Satakopan and Karandikar, 1961) and in Arabic as Molleih or Nadewa (Täckholm, 1974). In folklore medicine, the plant

*Corresponding Author

Sahar Y. Al-Okbi, Nutrition and Food Sciences Department, National

Research Centre, Cairo, Egypt.E-mail: S_Y_alokbi@hotmail.com

This article was presented at the 5th Euro-Mediterranean Conference and Expo on

Life Sciences, Pharma and Biomedicine (BioNat-V), Limassol, Cyprus. is used for combating ulcers, diabetes, leprosy, asthma, urinary disorders, and constipation and as a stomachic, aphrodisiac, and tonic (Priyashree et al., 2010). In Bahrain, the plant is used as expectorant and anti-bilious, while in Sudan, the leaves are dried and crushed with sugar to be used as an emetic (Macdonald, 1997).

Different phytochemical constituents were identified in $C$. cretica L., including phenolic compounds, coumarins, terpenic compounds, and sterols. Shahat et al. (2005) isolated five flavonoids from the ethyl acetate fraction of the methanol extract of aerial parts of C. cretica L. using column chromatography. The compound specifically identification based on thin layer chromatographic behavior and spectroscopic methods (UV, FAB-MS, ${ }^{1} \mathrm{H}-\mathrm{NMR}$, and $\left.{ }^{13} \mathrm{C}-\mathrm{NMR}\right)$ were quercetin, quercetin3-O-glucoside, kaempferol-3-O- glucoside, kaempferol-3-Orhamnoglucoside, and rutin. Concerning lignans, Shahat et al. (2004) isolated syringaresinol- $\beta$-d-glucoside from the aerial parts 
of $C$. cretica $\mathrm{L}$. The structure was deduced based on ${ }^{1} \mathrm{H}-\mathrm{NMR}$ and revised ${ }^{13} \mathrm{C}-\mathrm{NMR}$ assignment compared with the published report.

Coumarins isolated from the aqueous extract of the aerial parts of $C$. cretica L. through chemical and chromatographic fractionation were umbelliferone, scopoletin, and isopimpinellin (Rastogi and Mehrotra, 2005), while coumaranochromone glycoside, designated as cresoside was isolated from the alcohol extract of the fruits of C. cretica L. (Bahar, 1998).

From the lipoidal matter eight acyclic terpenic compounds, namely, cressanyl esters and cressa triterpenic acid were isolated from the aerial part extracts of C. cretica L. using silica gel column chromatography. Seven compounds, namely, triacontanoic acid (Melissic acid), 24-hydroxy-4-octacosanone, 24-nor-12-ursene, $\beta$-amyrin, ursolic acid, stigmasterol, and stigmasterol 3-O- $\beta$-D-glucoside were also isolated from the plant. Their structures have been elucidated by EI-MS, HREIMS, FAB, HRFAB-MS, ${ }^{1} \mathrm{H}$, and ${ }^{13} \mathrm{C}$ NMR spectroscopic data (Ramachandran and Ali, 2003). $\beta$-sitosterol and its glycoside, $n$-octacosanol, were isolated from the aqueous extract of the aerial parts of $C$. cretica L. through chromatographic fractionation (Rastogi and Mehrotra, 2005).

Petroleum ether, ethyl acetate, $n$-butanol, and aqueous fractions from $80 \%$ ethanol extract of $C$. cretica L. showed in vitro hepatoprotective effect; $n$-butanol was superior (Thirunavukkarasu et al., 2014). In vitro antioxidant activity of ethyl acetate and methanol extracts showed promising results. The same extracts exhibited anti-inflammatory activity in both acute and chronic models of inflammation in animals (Sunita et al., 2011).

The objective of the present work was to study the phytochemical constituents of the aerial parts of $C$. cretica L., Family Convolvulaceae growing in Egypt and the antioxidant and hepatoprotective activities as well as the safety of its different successive extracts.

\section{MATERIAL AND METHODS}

\section{Plant material}

Aerial parts of C. cretica L., Family: Convolvulaceae were collected from the road to Qaron lake, El-Fayoum, Egypt in December 2014. The sample was kindly authenticated by Dr. Abd Elhalim Abd El Motagali, Professor of Flora and Phyto Taxonomy Researches- Horticultural Research Inst. - Agriculture Research Centre-Dokki- Giza (Egypt). The voucher specimen number was 23-2-2015 A and was kept in the herbarium of the Pharmacognosy Department, Faculty of Pharmacy, Cairo University.

\section{Animals}

Animals (Mice and rats) were obtained from the Animal House, National Research Centre, Egypt. Male Wistar albino rats of body weight ranging from 100 to $120 \mathrm{~g}$ were used in the hepato-protective study. They were kept in a controlled environment of air and temperature. Water and food were given ad libitum with 12 hours light/dark cycle. Male and female albino senile mice of average body weight of $23 \mathrm{~g}$ were used in the acute toxicity test. Mice were kept as 10 mice/ cage with free access to water and food.

All animal procedures were performed after approval from the Ethics Committee of the National Research Centre and in accordance with the recommendations for the proper care and use of laboratory animals (NIH publication No. 85-23, revised 1985). Anesthetic procedures and handling of animals complied with the ethical guidelines of Medical Ethical Committee of the National Research Centre, Egypt (Approval No: 15027) and also approved from the research ethics committee for experimental and clinical studies of Faculty of Pharmacy Cairo University, Cairo, Egypt (Approval No. MP1328).

\section{Chemicals and drugs}

- All chemicals and solvents used in the present study were of high analytical grade.

- Silymarin was purchased from SEDICO Pharmaceuticals Company, Egypt.

\section{Preparation of successive extracts of $C$. cretica $\mathrm{L}$.}

The collected aerial parts of the plant were air-dried, powdered, and kept in tightly-closed containers. The powdered plant was extracted successively, in a continuous extraction apparatus (Soxhlet) using the following successive solvents with increasing polarities: Petroleum ether $\left(40^{\circ} \mathrm{C}-60^{\circ} \mathrm{C}\right)$, diethyl ether, methylene chloride, ethyl acetate, and $70 \%$ ethanol. The solvents in the prepared extracts were evaporated to dryness under vacuum at $40^{\circ} \mathrm{C}$. The extracts were weighed and kept for phytochemical and biological studies.

\section{Determination of total phenolic and flavonoidal contents of ethyl acetate and ethanol extracts of $C$. cretica $\mathrm{L}$.}

Nearly, $10 \mathrm{mg}$ of each extract was dissolved into $10 \mathrm{ml}$ methanol using ultrasonic sonicator for 10 minutes, then filtered and stored for analysis.

The total phenolic content (TPC) was determined according to the Folin-Ciocalteu procedure (Zilic et al., 2012). TPC was measured as Gallic acid equivalents using UV/VIS, 2041 spectrophotometer. Briefly, each tested sample $(100 \mu \mathrm{l})$ was transferred into a test tube and the volume adjusted to $3.5 \mathrm{ml}$ with distilled water and oxidized with the addition of $250 \mu \mathrm{l}$ of FolinCiocalteau reagent. After 5 minutes, the mixture was neutralized with $1.25 \mathrm{ml}$ of $20 \%$ aqueous sodium carbonate $\left(\mathrm{Na}_{2} \mathrm{CO}_{3}\right)$ solution. After 40 minutes, the absorbance was measured at $725 \mathrm{~nm}$. The total phenolic content was determined by means of a standard calibration curve prepared with Gallic acid and expressed as mg of Gallic acid equivalent (mg GAE) per $g$ of sample. The standard solution of Gallic acid (Fluka) was prepared. A calibration was constructed over the range of $5-50 \mu \mathrm{g} / \mathrm{ml}$ by diluting the stock solution $(1 \mathrm{mg} / \mathrm{ml})$ in methanol and treated as before. The absorbance of different concentrations of the standard solution was measured.

The total flavonoidal content was determined according to Zilic et al. (2012) using aluminum chloride $\left(\mathrm{AlCl}_{3}\right)$ colorimetric assay. Briefly, $300 \mu \mathrm{l}$ of $5 \%$ sodium nitrite $\left(\mathrm{NaNO}_{2}\right)$ was mixed with $100 \mu \mathrm{l}$ of each tested sample. After 6 minutes, $300 \mu \mathrm{l}$ of a $10 \% \mathrm{AlCl}_{3}$ solution was added and the volume was adjusted to $2.5 \mathrm{ml}$ using distilled water. After 7 minutes, $1.5 \mathrm{ml}$ of $1 \mathrm{M}$ $\mathrm{NaOH}$ was added, and the mixture was centrifuged at 5,000 $\mathrm{g}$ for 10 minutes. Absorbance of the supernatant was measured at 510 $\mathrm{nm}$. The total flavonoidal content was determined by means of a standard calibration curve prepared with catechin and expressed 
as milligrams of catechin equivalent ( $\mathrm{mg} \mathrm{CE}$ ) per $\mathrm{g}$ of sample. The standard solution of catechin was prepared. A calibration was constructed for the absorbance measurements of different concentrations of the standard solution over the range of 2.5-25 $\mu \mathrm{g} / \mathrm{ml}$ by diluting the stock solution $(1 \mathrm{mg} / \mathrm{ml})$ in methanol.

Qualitative and quantitative HPLC analysis of the ethyl acetate and ethanol extracts of $C$. cretica $\mathrm{L}$. for different phenolic and flavonoid compounds

Nearly, $50 \mathrm{mg}$ of ethyl acetate and $70 \%$ ethanol extracts were reconstituted separately in $2 \mathrm{ml}$ methanol (HPLC grade). HPLC analysis was carried out according to Kim et al. (2006) using HPLC apparatus (Agilent Technologies 1100 series liquid chromatography) using the following conditions: Column type: Eclipse XDB-C18 (particle size $5 \mu \mathrm{m}$ ), with a $\mathrm{C} 18$ guard column(Phenomenex, Torrance, CA); Column dimensions: 150 $\times 4.6 \mu \mathrm{m}$; Injector temperature: $35^{\circ} \mathrm{C}$; Mobile phase: acetonitrile (solvent $\mathrm{A}$ ) and $2 \%$ acetic acid in water (v/v) (solvent B); Flow rate: $0.8 \mathrm{ml} /$ minute for a total run time of 60 minutes; Detector: Diode-array detector set at 280, 320 and $360 \mathrm{~nm}$. The gradient program was as follows: $100 \% \mathrm{~B}$ to $85 \% \mathrm{~B}$ in 30 minutes, $85 \%$ $\mathrm{B}$ to $50 \% \mathrm{~B}$ in 20 minutes, $50 \% \mathrm{~B}$ to $0 \% \mathrm{~B}$ in 5 minutes, and $0 \%$ $\mathrm{B}$ to $100 \% \mathrm{~B}$ in 5 minutes. All samples were filtered through a $0.45 \mu \mathrm{m}$ Acrodisc syringe filter (Gelman Laboratory, MI) before injection. The injection volume was $20 \mu$ l. Peaks were monitored simultaneously at 280,320, and $360 \mathrm{~nm}$. Peaks were identified in comparison with those of the standards.

\section{Investigation of lipoidal matter}

Preparation of lipoidal matter was carried out by extraction with petroleum ether $\left(40^{\circ} \mathrm{C}-60^{\circ} \mathrm{C}\right)$. Saponification of petroleum ether extract and methylation of fatty acids were performed according to Tsuda et al. (1960) and Finar (1967).

GC/Mass apparatus used was Thermo Scientific, Trace GC Ultra \& ISQ Single Quadruple MS, under the following condition: Capillary column: TG-5MS fused silica capillary column (30 m, $0.25 \mathrm{~mm}, 0.25 \mu \mathrm{m}$ film thickness), Carrier Gas: Helium at a constant flow rate of $1 \mathrm{ml} /$ minute. The injection and MS transfer line temperature was set at $280^{\circ} \mathrm{C}$.

For unsaponifiable matter, the oven temperature was programmed at an initial temperature $50^{\circ} \mathrm{C}$ (hold 2 minutes) to $150^{\circ} \mathrm{C}$ at an increasing rate of $7^{\circ} \mathrm{C} /$ minute then to $270^{\circ} \mathrm{C}$ at an increasing rate of $5^{\circ} \mathrm{C} /$ minute (hold 2 minutes) then to $310^{\circ} \mathrm{C}$ as a final temperature at an increasing rate of $3.5^{\circ} \mathrm{C} /$ minute (hold 10 minutes).

For saponifiable matter fatty acid methyl esters: The oven temperature was programmed at an initial temperature $150^{\circ} \mathrm{C}$ (hold 4 minutes) to $280^{\circ} \mathrm{C}$ as a final temperature at an increasing rate of $5^{\circ} \mathrm{C} /$ minute (hold 4 minutes).

Identification of the constituents was carried out by comparison of the retention time, and mass spectral fragmentation patterns with those of the available database libraries (Wiley Int.), (NIST) and/or published data (Adams, 1995).

\section{Determination of trace elements of the aerial parts of $C$. cretica $\mathrm{L}$.}

Determination of trace elements was carried out by atomic absorption spectroscopy (Raje et al., 2006). Dry ashing digestion method was used (Chapman and Pratt, 1978) and the resultant ash was dissolved by $\mathrm{HCl}(2 \mathrm{~N})$. Manganese (Mn), zinc $(\mathrm{Zn})$, and copper $(\mathrm{Cu})$ were extracted by diethylenetriamine penta acetic acid according to Lindsay and Norvell (1978) and measured in the suspension using atomic absorption spectrophotometer Perkin-Elemer (Model 1100).

\section{Free radical scavenging activity procedure}

The free radical scavenging activity of the different successive extracts was evaluated using in vitro assay; 2,2-diphenyl1-picryl-hydrazyl (DPPH) by the method described by Romano et al. (2009). The extracts were dissolved separately in DMSO at a concentration range of $125-1,000 \mu \mathrm{g} / \mathrm{ml}$. The assay was performed in a 96-well flat bottom microplate with $180 \mu \mathrm{l}$ of $0.004 \%$ DPPH solution in methanol and $20 \mu \mathrm{l}$ of each tested solution. The mixture was left in dark for 30 minutes at room temperature then the absorbance was measured spectrophotometrically against blank at $517 \mathrm{~nm}$ in assays microplate reader. Ascorbic acid was used as a standard at concentrations of $0.5-1 \mu \mathrm{g} / \mathrm{ml}$. Lower absorbance of the reaction mixture indicated higher free radical scavenging activity.

The inhibition \% of DPPH radical scavenging activity was calculated according to the following formula:

$$
\text { Inhibition }(\%)=\left[\frac{\left(A_{0}-A_{1}\right)}{A_{0}} \times 100\right]
$$

where $A_{0}$ was the absorbance of the control reaction and $A_{1}$ was the absorbance in the presence of the extract or ascorbic acid as reference material. Each measurement was performed in triplicate $(n=3)$ (Oktay et al., 2003). $\mathrm{IC}_{50}$ value (the dose that produces $50 \%$ inhibition) of ascorbic acid was determined. The low the $\mathrm{IC}_{50}$ the strong is the antioxidant activity.

\section{Acute toxicity test}

The acute toxicity test of the different successive extracts (five extracts) was carried out. Each extract was tested in 60 mice (6 groups; each of 10 mice). Each extract was given in different doses starting from $0.5 \mathrm{~g} / \mathrm{kg}$ mice body weight until $3 \mathrm{~g} / \mathrm{kg}$ (i.e., $0.5,1,1.5,2,2.5$, and $3 \mathrm{~g} / \mathrm{kg})$. After 24 hours, the dead mice were recorded in each group.

\section{Hepatoprotective experiment}

$\mathrm{CCl}_{4}$ was used for liver intoxication in rats. $\mathrm{CCl}_{4}$ was prepared by mixing one $\mathrm{ml}$ of $\mathrm{CCl}_{4}$ with $9 \mathrm{ml}$ of olive oil. $\mathrm{CCl}_{4}$ mixture $(0.5 \mathrm{ml})$ was given to rats two times weekly for 4 weeks through intraperitoneal injection (Marsillach et al., 2009).

Silymarin, a reference hepatoprotective herbal drug, was given as a daily oral dose of $50 \mathrm{mg} / \mathrm{kg}$ rat body weight, for 4 weeks according to Sharma et al. (2012).

Petroleum ether, ethyl acetate extract, and 70\% ethanol extracts that showed complete safety from the acute toxicity test were used for the hepatoprotective test. The applied dose from each extract was a daily oral dose of $500 \mathrm{mg} / \mathrm{kg}$ rat body weight for 4 weeks.

Nearly, 90 male albino rats were used in this study. Animals were divided randomly into nine groups (10 rats each). Group 1 served as normal healthy control rats. Groups 2-4 were normal healthy rats orally administered petroleum ether, ethyl 
acetate, and $70 \%$ ethanol extract of $C$. cretica Linn, respectively. Group 5 was intraperitoneally injected with $\mathrm{CCl}_{4}$ and considered as control liver intoxicated rats. Groups $6-8$ were injected by $\mathrm{CCl} 4$ and co-administered with a daily oral dose of petroleum ether, ethyl acetate and $70 \%$ ethanol extracts, respectively. Besides, a group of rats (the 9th group) was injected with $\mathrm{CCl}_{4}$ and given a daily oral dose of silymarin. The experiment continued for 4 weeks. At the end of the experiment, blood samples were collected from fasted anesthetized animals by puncture of the sub-tongual vein and centrifuged at $3,000 \mathrm{rpm}$ at $4^{\circ} \mathrm{C}$ for 15 minutes. The separated serum was used for determinations of liver function indices represented by aspartate and alanine aminotransferases (AST and ALT) by the method of Reitman and Frankel (1957), alkaline phosphatase (ALP) according to Bergmeyer et al. (1980) and total bilirubin (Bruckner, 1961). Also, serum total antioxidant capacity (TAC) was estimated according to Koracevic et al. (2001) as a biomarker of antioxidant status. Rats were dissected after decapitation and liver was separated from each rat. A part of the liver $(0.5 \mathrm{~g})$ was instantaneously homogenized for assaying the enzymatic antioxidants; catalase (CAT) (Bruckner, 1961) and superoxide dismutase (SOD) activities according to Nishikimi et al. (1972). Also, the non-enzymatic antioxidant, reduced glutathione (GSH) was determined in the liver according to Moron et al. (1979). Liver malondialdehyde (MDA) was assessed as a biomarker of lipid peroxidation and oxidative stress adopting the method of Buege and Aust (1978). Liver nitric oxide (NO) was assessed as a biomarker of both inflammation and oxidative stress according to Anguo et al. (2013). Another part of each liver was placed in $10 \%$ formaldehyde and then embedded in paraffin wax blocks. Sections of $5 \mu \mathrm{m}$ thickness were stained with different stains [hemotoxylin and Eosin (H\& E) and Masson's Trichrome] then examined under light microscope for examination of pathological changes (Hirsch et al., 2004).

\section{Statistical analysis}

All data were expressed as Mean \pm standard deviation of the mean (SD) of 10 rats in each group. Statistical analysis was carried out using one-way analysis of variance (version 8) coupled with Co-stat Software Computer Program, where unshared letters are significant at $p \leq 0.05$.

\section{RESULTS}

Total phenolic and flavonoidal contents of ethyl acetate and ethanol extracts of $C$. cretica $\mathrm{L}$.

The results obtained for the total phenolic and total flavonoidal contents for ethyl acetate and ethanol extracts showed that the TP contents were 21.07 and $22.95 \mathrm{mg} \mathrm{GAE} / \mathrm{g}$, respectively. The TF content of the ethyl acetate and ethanol extracts were 6.25 and $10.18 \mathrm{mg} \mathrm{CE} / \mathrm{g}$, respectively. The TF content of the ethanol extract was higher than that of its respective ethyl acetate where it was $\sim 1.5$-fold.

\section{Phenolic and flavonoid compounds of ethyl acetate and ethanol extracts identified by HPLC}

Flavonoids and phenolic compounds are demonstrated in Table 1. The data obtained by HPLC analysis of ethyl acetate extract identified 17 compounds; 12 phenolic compounds with catechin as the major one $(1,219.14 \mu \mathrm{g} / \mathrm{g})$ and five flavonoid compounds with rutin being the major one $(318.30 \mu \mathrm{g} / \mathrm{g})$. HPLC

Table 1. Phenolic profile of the ethyl acetate and ethanol extracts of C. cretica $\mathrm{L}$.

\begin{tabular}{|c|c|c|c|c|}
\hline \multirow[b]{2}{*}{ No. } & \multirow[b]{2}{*}{ Compound } & \multirow[b]{2}{*}{$R_{\mathrm{t}}$} & \multicolumn{2}{|c|}{ Conc. $(\mu \mathrm{g} / \mathrm{g})$} \\
\hline & & & $\begin{array}{l}\text { EtOAc ext. of } \\
\text { C. cretica }\end{array}$ & EtOH ext. of $C$. cretica \\
\hline 1 & Gallic acid & 5.78 & ND & 66.76 \\
\hline 2 & $\begin{array}{l}\text { Protocatechuic (3,4-dihydroxybenzoic } \\
\text { acid) }\end{array}$ & $10-10.4$ & 100.75 & 106.89 \\
\hline 3 & $p$-hydroxybenzoic & $15.7-15.9$ & 271.80 & ND \\
\hline 4 & Gentisic acid (2,5-dihydroxy benzoic) & 16.77 & 64.47 & 89.30 \\
\hline 5 & Catechin & $19.3-19.5$ & 1219.14 & 193.99 \\
\hline 6 & Chlorogenic & 21.5 & 47.30 & 2247.66 \\
\hline 7 & Caffeic acid & $22.2-22.3$ & 219.55 & 882.23 \\
\hline 8 & Vanillic acid & 25.5 & 69.77 & 5.82 \\
\hline 9 & Ferulic acid & 33.2 & 49.00 & 21.59 \\
\hline 10 & $\begin{array}{l}\text { Sinapic (3,5-Dimethoxy-4- } \\
\text { hydroxycinnamic acid) }\end{array}$ & 34.48 & 32.17 & 59.09 \\
\hline 11 & Rutin & 36.4 & 318.30 & 760.25 \\
\hline 12 & $p$-coumaric & 37.5 & 76.37 & 579.43 \\
\hline 13 & Apigenin-7-glucoside & 39 & 79.65 & 1761.75 \\
\hline 14 & Rosmarinic & 39.7 & 100.82 & 33.00 \\
\hline 15 & Cinnamic & 42.9 & 17.59 & 29.62 \\
\hline 16 & Quercetin & 43.5 & 18.74 & 279.17 \\
\hline 17 & Apigenin & 45.9 & 49.61 & ND \\
\hline 18 & Kaempferol & 46.4 & 14.23 & 92.90 \\
\hline
\end{tabular}

$R_{\mathrm{t}}=$ retention time, EtOAc ext. $=$ ethyl acetate extract, EtOH ext. $=$ ethanol extract. 
analysis of ethanol extract showed 16 compounds; 12 phenolic compounds with chlorogenic acid being the major one $(2,247.66$ $\mu \mathrm{g} / \mathrm{g}$ ) and four flavonoid compounds with apigenin-7-glucoside as the main components $(1,761.75 \mu \mathrm{g} / \mathrm{g})$.

\section{GC/MS analysis of lipoidal matter (USM and FAME)}

The yield of lipoidal matter was found to be $1.67 \%$

Unsaponifiable matter (USM) is illustrated in Table 2, which revealed the identification of 21 compounds representing $60.3 \%$ of the total compounds. Phenol was the major one $(12.90 \%)$. Total hydrocarbons (13 compounds) represented by $61.9 \%$ with heptacosane and nonacosane as the most abundant $(5.30 \%$ and $4.72 \%$, respectively). Two steroidal compounds $\beta$-sitosterol $(1.58 \%)$ and $\alpha$-sitosterol $(1.18 \%)$ in addition to one triterpenoidal compound [ $\beta$-amyrin (1.29\%)] were detected. Phytol, acyclic diterpene alcohol was identified $(2.56 \%)$.

Gas chromatography-mass spectrometry (GC/MS) analysis of fatty acid methyl ester (FAME): Table 3 revealed the identification of 16 compounds representing $87.82 \%$ of the total matter. Fourteen saturated fatty acids representing $87.5 \%$ of the total identified compounds with 14-methyl-Pentadecanoic acid $\left(\mathrm{C}_{15}\right)(24.82 \%)$ being the major one followed by tetracosanoic acid $\left(\mathrm{C}_{24}\right)(12.31 \%)$, hexacosanoic acid $\left(\mathrm{C}_{26}\right)(11.78 \%)$, docosanoic acid $\left(\mathrm{C}_{22}\right)(9.11 \%)$, and octacosanoic acid $\left(\mathrm{C}_{28}\right)(8.98 \%)$. Two unsaturated fatty acid representing $12.5 \%$ of the total identified compounds; 5-octadecenoic acid $\left(\mathrm{C}_{18.1}\right)$ (4.05\%) and 9, 12-octadecadienoic acid $\left(\mathrm{C}_{18: 2}\right)(2.32 \%)$ were also detected.

\section{Trace elements contents of $C$. cretica $\mathrm{L}$.}

Manganese, zinc, and copper were detected in C. cretica L. in the concentration of $132,40.5$, and $22.5 \mathrm{ppm}$, respectively.

Free radical scavenging activity of the different successive extracts

Table 4 showed that the DPPH radical scavenging activity of different extracts correlated with the dose level; $70 \%$ ethanol extract of $C$. cretica $\mathrm{L}$. had the most potent anti-oxidant activity against DPPH radical compared with other extracts. The IC50 of ascorbic acid was $12.433 \mu \mathrm{g} / \mathrm{ml}$.

\section{Acute toxicity}

The results of acute toxicity showed petroleum ether, ethyl acetate, and $70 \%$ ethanol extracts of $C$. cretica $\mathrm{L}$. to be safe up to $3 \mathrm{~g} / \mathrm{kg}$ mice body weight, while diethyl ether and dichloromethane were safe up to 1 and $0.5 \mathrm{~g} / \mathrm{kg}$, respectively.

\section{Hepatoprotective activity of the plant extracts}

Table 5 demonstrated the biochemical parameters of different experimental groups. Results showed an insignificant change in enzymatic and non-enzymatic antioxidants; liver SOD, GSH, catalase, and serum TAC and oxidative stress biomarkers; liver MDA and NO levels in normal rats treated with petroleum ether, ethyl acetate and $70 \%$ ethyl alcohol extracts of $C$. cretica L. compared with normal control. $\mathrm{CCl}_{4}$-intoxicated rats (liver cirrhotic control) revealed a significant decrease in SOD, GSH,

Table 2. GC/MS analysis of the USM of the aerial parts of C. cretica L.



$\mathrm{M} . \mathrm{W}=$ molecular weight, $R_{\mathrm{t}}=$ retention time. 
catalase, and TAC along with a significant increase in MDA and NO level compared with normal control.

Treatment of $\mathrm{CCl}_{4}$ intoxicated rats with petroleum ether, ethyl acetate, and $70 \%$ ethanol extracts as well as silymarin produced significant improvement in the abovementioned biomarkers compared to control liver intoxicated rats. The improvement was more or less similar in all tested groups (liver intoxicated rats + extracts) along with that of the reference drug concerning SOD, MDA, and TAC. Improvement of GSH by ethyl acetate fraction and silymarin was similar and superior to other treatments where its level was normalized. Nitric oxide returned to normal level when treated by either silymarin or $70 \%$ ethanol extract. On the other hand, treatment with $70 \%$ alcohol extract was superior to all test groups including silymarin in improving catalase level that matched that of the normal control group.
Table 5 showed an insignificant change in liver function enzyme activities ALT, AST, ALP, and total bilirubin level in control rats treated with petroleum ether, ethyl acetate, and $70 \%$ ethanol extracts of $C$. cretica L compared with normal control. However, a significant increase in ALT, AST, and ALP activities and total bilirubin level was noticed in liver intoxicated control rats compared with normal control.

Treatment by different extracts with concomitant CCl4 intoxication produced significant improvement in ALT, AST, and ALP activity and total bilirubin level compared with liver intoxicated control rats. Treatment of CCl4 intoxicated rats with silymarin and $70 \%$ ethanol extract showed to be superior in improving ALT and ALP activity significantly compared with other test groups. The intoxicated groups received ethyl acetate and 70\% ethanol produced a significant reduction in AST activity compared

Table 3. GC/MS analysis of FAME of the aerial parts of C. cretica $\mathrm{L}$.

\begin{tabular}{|c|c|c|c|c|c|c|}
\hline No. & Compound name & $R_{\mathrm{t}}$ & BP & M.W & Molecular formula & Area \% \\
\hline 1 & Octanoic acid $\left(\mathrm{C}_{8}\right)$; Caprylic acid & 11.11 & 74 & 158 & $\mathrm{CH}_{3}\left(\mathrm{CH}_{2}\right)_{6} \mathrm{COOH}$ & 1.26 \\
\hline 2 & 14-methyl-Pentadecanoic acid $\left(\mathrm{C}_{15}\right)$ & 15.87 & 55 & 270 & $\begin{array}{l}\mathrm{CH}_{3} \mathrm{C}-\mathrm{CH}\left(\mathrm{CH}_{2}\right)_{11} \mathrm{COOH} \\
\quad \mathrm{CH}_{3}\end{array}$ & 24.82 \\
\hline 3 & 14-methyl-Hexadecanoic acid $\left(\mathrm{C}_{16}\right)$ & 18.8 & 55 & 284 & $\begin{array}{c}\mathrm{CH}_{3} \mathrm{CH}-\mathrm{CH}\left(\mathrm{CH}_{2}\right)_{12} \mathrm{COOH} \\
\mathrm{CH}_{3}\end{array}$ & 0.36 \\
\hline 4 & $\begin{array}{l}\text { 9,12-Octadecadienoic acid }\left(\mathrm{C}_{18: 2}\right) ; \text { (Linoleic } \\
\text { acid) }\end{array}$ & 19.73 & 67 & 294 & $\mathrm{CH}_{3}\left(\mathrm{CH}_{2}\right)_{4} \mathrm{CH}=\mathrm{CHCH}_{2} \mathrm{CH}=\mathrm{CH}\left(\mathrm{CH}_{2}\right)_{7} \mathrm{COOH}$ & 2.32 \\
\hline 5 & 5-octadecenoic acid $\left(\mathrm{C}_{18: 1}\right)$ & 19.87 & 55 & 296 & $\mathrm{CH}_{3}\left(\mathrm{CH}_{2}\right)_{11} \mathrm{CH}=\mathrm{CH}(\mathrm{CH})_{3} \mathrm{COOH}$ & 4.05 \\
\hline 6 & $\begin{array}{l}\text { Octadecanoic acid }\left(\mathrm{C}_{18}\right) \\
\text { (Stearic acid) }\end{array}$ & 20.45 & 74 & 298 & $\mathrm{CH}_{3}\left(\mathrm{CH}_{2}\right)_{16} \mathrm{COOH}$ & 6.98 \\
\hline 7 & Nonadecanoic acid $\left(\mathrm{C}_{19}\right)$ & 24.28 & 74 & 312 & $\mathrm{CH}_{3}\left(\mathrm{CH}_{2}\right)_{17} \mathrm{COOH}$ & 0.30 \\
\hline 8 & Eicosanoic acid $\left(\mathrm{C}_{20}\right)$; Arachidic acid & 24.74 & 74 & 326 & $\mathrm{CH}_{3}\left(\mathrm{CH}_{2}\right)_{18} \mathrm{COOH}$ & 3.48 \\
\hline 9 & Heneicosanoic $\operatorname{acid}\left(\mathrm{C}_{21}\right)$ & 26.76 & 74 & 340 & $\mathrm{CH}_{3}\left(\mathrm{CH}_{2}\right)_{19} \mathrm{COOH}$ & 0.30 \\
\hline 10 & Docosanoic acid $\left(\mathrm{C}_{22}\right)$; Behenic acid & 28.75 & 74 & 354 & $\mathrm{CH}_{3}\left(\mathrm{CH}_{2}\right)_{20} \mathrm{COOH}$ & 9.11 \\
\hline 11 & Tricosanoic acid $\left(\mathrm{C}_{23}\right)$ & 30.61 & 74 & 368 & $\mathrm{CH}_{3}\left(\mathrm{CH}_{2}\right)_{21} \mathrm{COOH}$ & 0.59 \\
\hline 12 & Tetrecosanoic acid $\left(\mathrm{C}_{24}\right)$; Lignoceric acid & 32.47 & 74 & 382 & $\mathrm{CH}_{3}\left(\mathrm{CH}_{2}\right)_{22} \mathrm{COOH}$ & 12.31 \\
\hline 13 & Pentacosanoic acid $\left(\mathrm{C}_{25}\right)$ & 34.19 & 74 & 396 & $\mathrm{CH}_{3}\left(\mathrm{CH}_{2}\right)_{23} \mathrm{COOH}$ & 0.70 \\
\hline 14 & Hexacosanoic acid $\left(\mathrm{C}_{26}\right)$ & 35.94 & 74 & 410 & $\mathrm{CH}_{3}\left(\mathrm{CH}_{2}\right)_{24} \mathrm{COOH}$ & 11.78 \\
\hline 15 & Heptacosanoic acid $\left(\mathrm{C}_{27}\right)$ & 37.61 & 74 & 424 & $\mathrm{CH}_{3}\left(\mathrm{CH}_{2}\right)_{25} \mathrm{COOH}$ & 0.48 \\
\hline 16 & Octacosanoic acid $\left(\mathrm{C}_{28}\right)$ & 39.68 & 74 & 438 & $\mathrm{CH}_{3}\left(\mathrm{CH}_{2}\right)_{26} \mathrm{COOH}$ & 8.98 \\
\hline Total identified & & & & & & $87.82 \%$ \\
\hline
\end{tabular}

$\mathrm{M} . \mathrm{W}=$ molecular weight, $R_{\mathrm{t}}=$ retention time, $\mathrm{BP}=$ base peak

Table 4. \% of DPPH radical scavenging activity of the prepared successive extracts of $C$. cretica $\mathrm{L}$.

\begin{tabular}{ccccc}
\hline $\begin{array}{c}\text { Concentrations } \\
(\boldsymbol{\mu g} / \mathbf{m l})\end{array}$ & $\mathbf{1 2 5}$ & $\mathbf{2 5 0}$ & $\mathbf{5 0 0}$ & $\mathbf{1 , 0 0 0}$ \\
\hline Extract type & & & & \\
Petroleum ether & 0 & 0.67 & 3.8 & 9.9 \\
Diethyl ether & 13.3 & 23.8 & 32.8 & 55.5 \\
Methylene chloride & 14.8 & 20.2 & 45 & 56.9 \\
Ethyl acetate & 19.6 & 22.04 & 40.03 & 49.3 \\
$70 \%$ Ethanol & 64 & 90 & 90.4 & 89.06 \\
\hline
\end{tabular}

The IC50 value of vitamin C was $12.433 \mu \mathrm{g} / \mathrm{ml}$. 


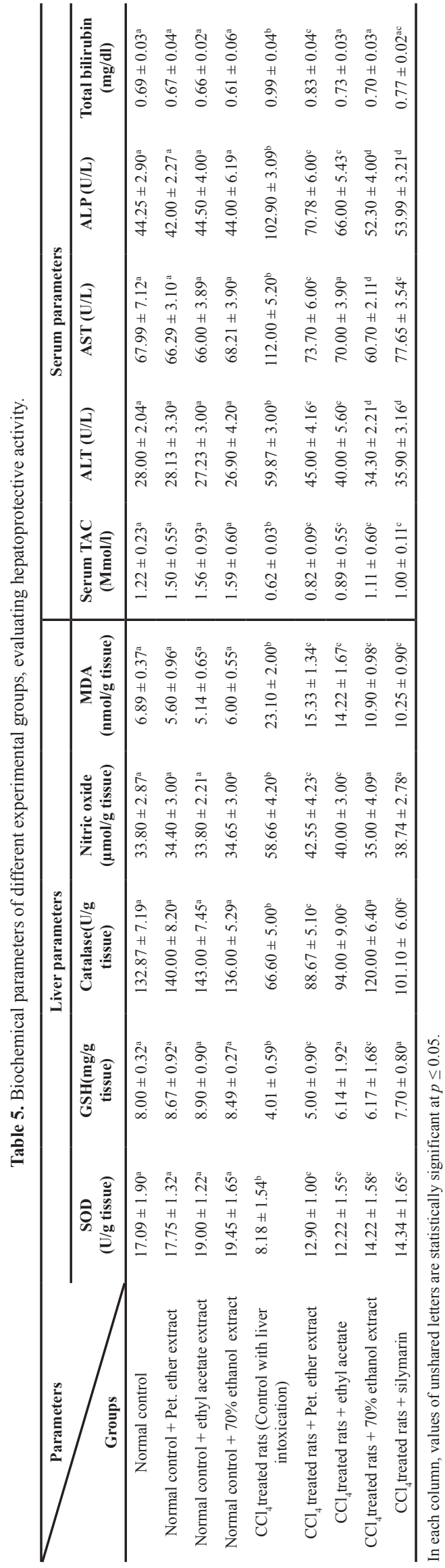

with either silymarin or petroleum ether treated groups. The level of total bilirubin showed insignificant change when the intoxicated rats treated with ethyl acetate and $70 \%$ ethanol were compared with that of silymarin group whereas significant reduction was encountered compared with petroleum ether treated group. AST activity was normalized when $\mathrm{CCl} 4$ intoxicated rats were treated by ethyl acetate while treatment with $70 \%$ ethanol extract showed significant reduction compared with normal control. Total bilirubin was normalized when intoxicated rats were treated by any of the extract or silymarin except for petroleum ether group.

Figure 1 shows the photomicrographs of histopathological changes of the liver of different experimental groups stained with H\& E while Figure 2 shows liver tissues stained with Masson's Trichrome. The score of liver lesions in the different experimental groups was demonstrated in Table 6.

In Figure 1, the liver of rats of the normal control group showed the normal histologic structure of hepatic lobule (Fig. 1.1). Liver of rats from normal groups treated by petroleum ether, ethyl acetate, and $70 \%$ ethanol extracts showed normal appearance (Fig. 1.2, 1.3, and 1.4). Meanwhile, liver of rats from $\mathrm{CCl} 4$ intoxicated control rats revealed fatty change of hepatocytes, fibroblasts proliferation and inflammatory cells infiltration (Fig. $1.5 \mathrm{~A}$ ) and karyomegally of hepatocytic nuclei with fibroplasia in the portal triad and hyperplasia of biliary epithelium with newly formed bile ductuoles (Fig. 1.5B). However, liver of rats from $\mathrm{CCl} 4$ intoxicated rats treated by petroleum ether extract showed strands of fibroblasts proliferation in the portal triad (Fig. 1.6A) and fatty change of hepatocytes (Fig. 1.6B). Liver of rats from $\mathrm{CCl} 4$ intoxicated rats treated by ethyl acetate extract revealed fine strands of fibroblasts proliferation in the portal triad and sinusoidal leucocytosis (Fig. 1.7A) and slight hydropic degeneration of hepatocytes (Fig. 1.7B). Liver sections from CCl4 intoxicated rats treated by $70 \%$ ethanol extract revealed hemosidrosis, karyomegally of hepatocytic nuclei, sinusoidal leukocytosis, and oval cells proliferation (Fig. 1.8A and B). Figure 1.9A, B, and C demonstrated liver of rats treated by $\mathrm{CCl} 4$ and silymarin showing fatty change of hepatocytes, oval cells proliferation, fibroplasia in the portal triad, hyperplasia of biliary epithelium with inflammatory cells infiltration and Kupffer cells activation. So, from Figure 1, it was observed that the treatment with different extracts exhibited variable reductions in the liver histopathological changes induced by $\mathrm{CCl} 4$ which could be more promising than silymarin.

In Figure 2, liver of rat from the normal control group, the normal group given pet. ether, ethyl acetate, and 70\% ethanol extract showed no histochemical reaction for collagen fibers deposition in the portal triad (Fig. 2.1-2.4). Liver of rats from CCl4 intoxicated control group demonstrated strong positive histochemical reaction for collagen fibers deposition in the portal triad (Fig. 2.5A and B). Liver intoxicated rats treated by CCl4 and petroleum ether extract displayed moderate positive histochemical reaction for collagen fibers deposition in the portal triad (Fig. 2.6). Liver of rats treated by $\mathrm{CCl} 4$ and ethyl acetate extract showed a weak positive histochemical reaction for collagen fibers deposition in the portal triad (Fig. 2.7A), while in Figure 2.7B, it exhibited moderate positive histochemical reaction for collagen fibers deposition in the portal triad. Figure 2.8 revealed that liver of rats treated by $\mathrm{CCl} 4$ and $70 \%$ alcohol extract showed a weak positive histochemical reaction for collagen fibers deposition in the 
Table 6. Histopathological lesion score of the liver of different experimental groups.

\begin{tabular}{|c|c|c|c|c|c|c|c|c|c|}
\hline $\begin{array}{c}\text { Groups } \\
\text { Liver lesions }\end{array}$ & Group 1 & Group 2 & Group 3 & Group 4 & Group 5 & Group 6 & Group 7 & Group 8 & Group 9 \\
\hline Fatty change of hepatocytes & - & - & - & - & +++ & +++ & - & - & ++ \\
\hline fibroblasts proliferation & - & - & - & - & +++ & ++ & + & ++ & ++ \\
\hline Oval cells proliferation & - & - & - & - & ++ & + & + & ++ & + \\
\hline Karyomegally & - & - & - & - & ++ & + & + & ++ & + \\
\hline inflammatory cells infiltration & - & - & - & - & +++ & + & - & ++ & - \\
\hline Deposition of haemosidrin & - & - & - & - & +++ & + & + & + & + \\
\hline Biliary hyperplasia & - & - & - & - & +++ & + & + & ++ & + \\
\hline
\end{tabular}

$-=$ no change, $+=$ mild change, $++=$ moderate change, $+++=$ severe change.

Group (1): Normal control, group (2): Normal control + petroleum ether extract, group (3): Normal control + ethyl acetate extract, group (4): Normal control + 70\% ethanol extract, group (5): $\mathrm{CCl}_{4}$-intoxicated control rats, group (6): $\mathrm{CCl}_{4}$-intoxicated rats + Pet. ether extract, group (7): $\mathrm{CCl}_{4}$-intoxicated rats + ethyl acetate extract., group $(8)$ : $\mathrm{CCl}_{4}$-intoxicated rats $+70 \%$ ethanol extract, group (9): $\mathrm{CCl}_{4}$-intoxicated rats + standard silymarin drug.

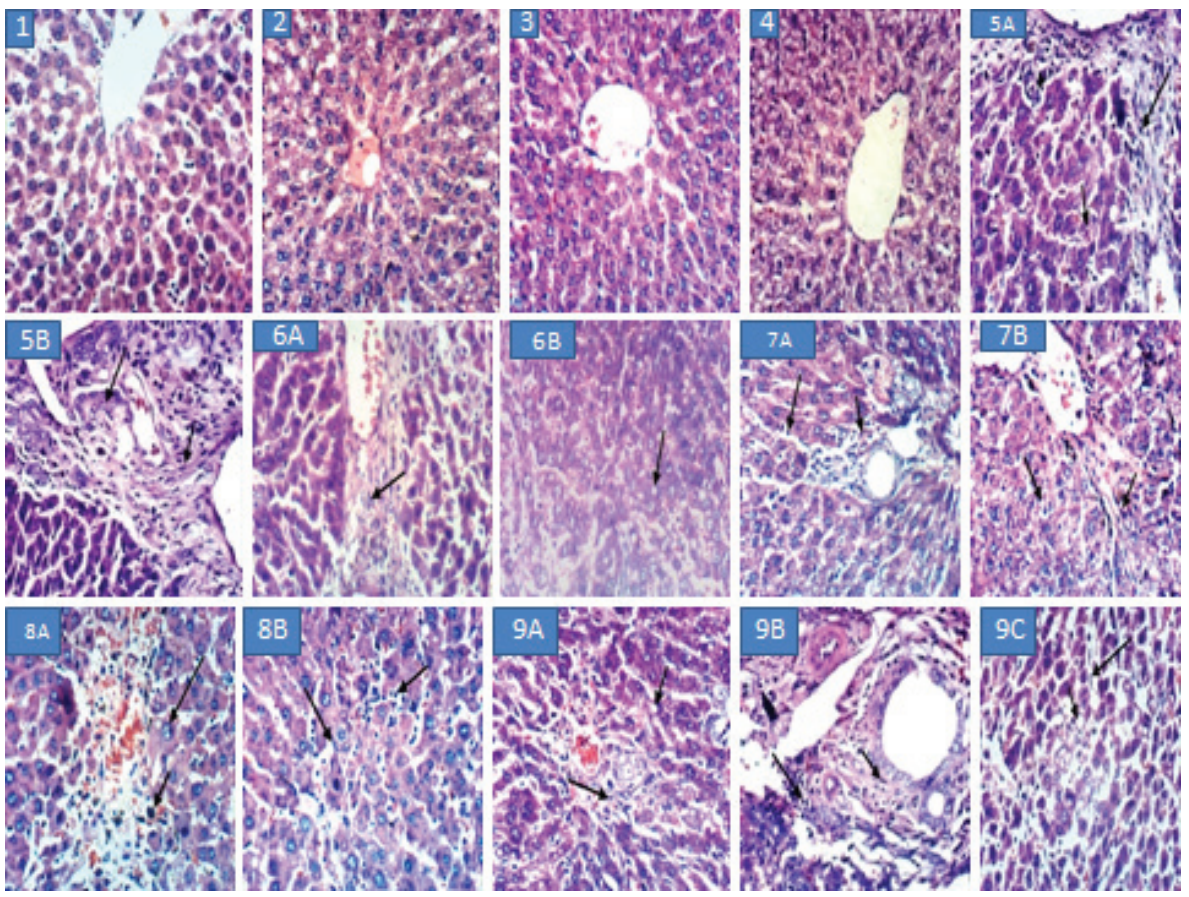

Figure 1. Photomicrographs of histopathological examination of the liver of different groups stained with H\& E $(\times 400)$. 1.1: Liver of rat from normal control group showing the normal histological structure of hepatic lobule. 1.2: Liver of rat from normal group given pet. ether extract showing no histopathological changes. 1.3: Liver of rat from normal group given ethyl acetate extract showing no histopathological changes. 1.4: Liver of rat from normal group given $70 \%$ ethanol extract with apparent normal hepatocyte. 1.5 (A and B): Liver of rats treated by $\mathrm{CCl}_{4}$ (Control intoxicated); (A) showing fatty change of hepatocytes, fibroblasts proliferation and inflammatory cells infiltration while (B) showing fibroplasia in the portal triad and hyperplasia of biliary epithelium with newly formed bile ductuoles. 1.6 (A and B): Liver of rats treated by $\mathrm{CCl}_{4}$ and pet. ether extract; (A) showing strands of fibroblasts proliferation in the portal triad while (B) showing fatty change of hepatocytes. 1.7 (A and B): Liver of rats treated by $\mathrm{CCl}_{4}$ and ethyl acetate extract; (A) showing fine strands of fibroblasts proliferation in the portal triad and sinusoidal leucocytosis while (B) showing fine strands of fibroblasts proliferation in the portal triad and hydropic degeneration of hepatocytes. 1.8 (A and B): Liver of rats treated by CCl ${ }_{4}$ and $70 \%$ alcohol extract; (A) showing hemosidrosis and karyomegally of hepatocytic nuclei while (B) showing sinusoidal leukocytosis and oval cells proliferation. 9 (A, $\mathrm{B}, \mathrm{C}$ ): Liver of rats treated by $\mathrm{CCl}_{4}$ and silymarin; (A) showing fatty change of hepatocytes and oval cells proliferation; (B) showing fibroplasia in the portal triad and hyperplasia of biliary epithelium with inflammatory cells infiltration while (C) showing fatty change of hepatocytes and Kupffer cells activation.

portal triad. Figure 2.9A and B: liver of rats treated by CCl4 and silymarin demonstrated moderate positive histochemical reaction for collagen fibers deposition in the portal triad (Fig. 2.9A), while in Figure 2.9 B, it showed a weak positive histochemical reaction for collagen fibers deposition in the portal triad. So, it can be concluded from Table 6 that the ethyl acetate extract was the most efficient in preventing the histopathological changes demonstrated on Masson's Trichrome stain and even better than silymarin.

\section{DISCUSSION}

In the present study, different successive extracts of C. cretica $\mathrm{L}$ were prepared and assessed for their phytochemical constituents, in vitro antioxidant activity and safety through acute toxicity test. The safest extracts represented by petroleum ether, ethyl acetate, and $70 \%$ ethanol extracts were tested for their potential hepatoprotective activity in relation to reference herbal drug, silymarin, with simultaneous assaying their safety during 

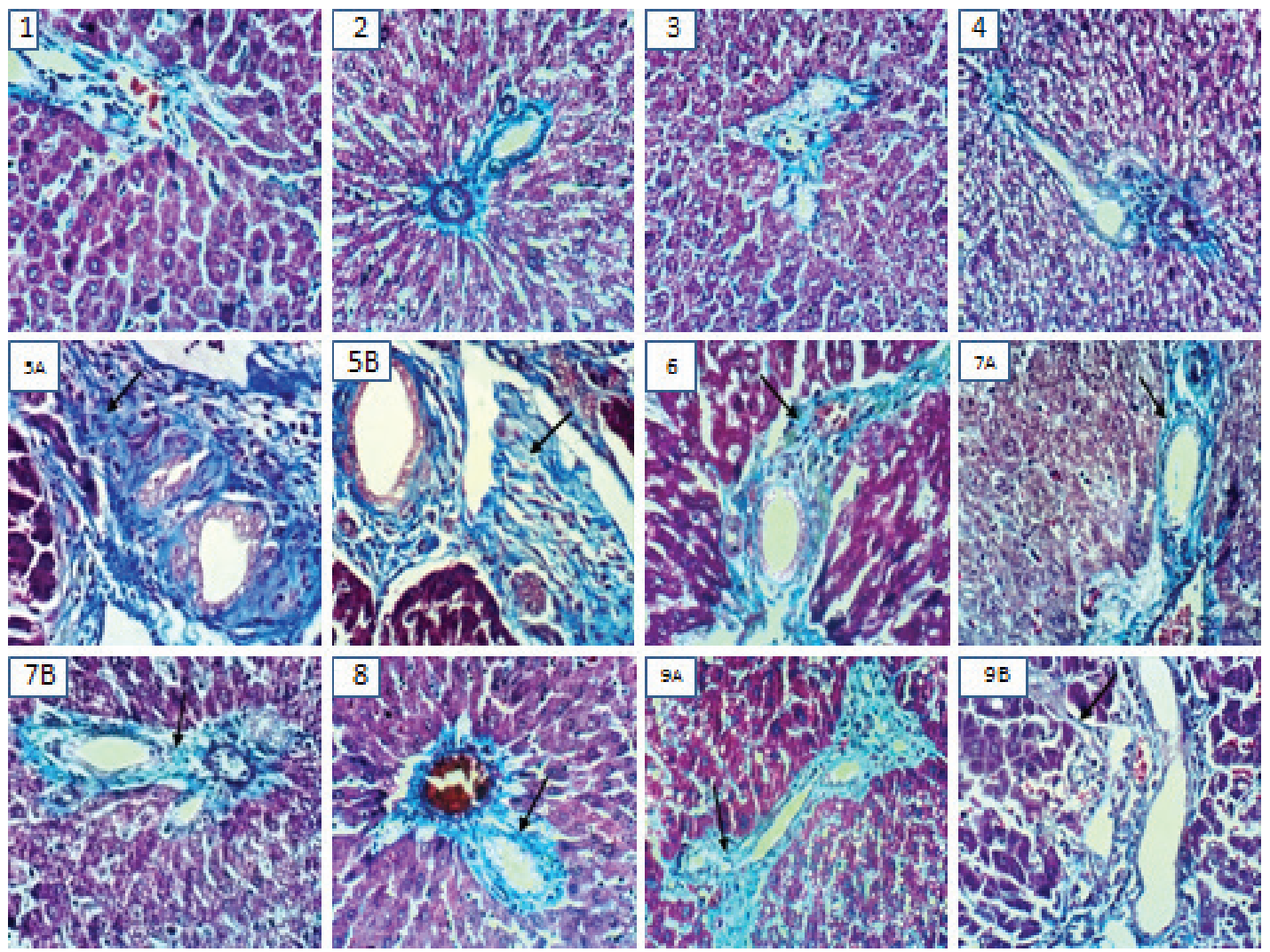

Figure 2. Photomicrographs of histopathological examination of the liver of different groups stained Masson's Trichrome ( $\times 400)$. 2.1: Liver of rat from normal control group showing no histochemical reaction for collagen fibers deposition in the portal triad. 2.2: Liver of rat from normal group given pet. ether extract showing no histochemical reaction for collagen fibers deposition in the portal triad. 2.3: Liver of rat from normal group given ethyl acetate extract showing no histochemical reaction for collagen fibers deposition in the portal triad. 2.4: Liver of rat from normal group given $70 \%$ ethanol extract showing no histochemical reaction for collagen fibers deposition in the portal triad. 2.5 (A and B): Liver of rats treated by $\mathrm{CCl}_{4}$ (Control intoxicated); (A) showing a strong positive histochemical reaction for collagen fibers deposition in the portal triad while (B) showing a strong positive histochemical reaction for collagen fibers deposition in the portal triad. 2.6: Liver of rats treated by $\mathrm{CCl}_{4}$ and pet. ether extract showing a moderate positive histochemical reaction for collagen fibers deposition in the portal triad. 2.7 (A and B): Liver of rats treated by $\mathrm{CCl}_{4}$ and ethyl acetate extract; (A) showing a weak positive histochemical reaction for collagen fibers deposition in the portal triad while (B) showing a moderate positive histochemical reaction for collagen fibers deposition in the portal triad. 2.8: Liver of rats treated by $\mathrm{CCl}_{4}$ and $70 \%$ alcohol extract showing a weak positive histochemical reaction for collagen fibers deposition in the portal triad. 2.9 (A and B): Liver of rats treated by $\mathrm{CCl}_{4}$ and silymarin; (A) showing a moderate positive histochemical reaction for collagen fibers deposition in the portal triad while (B) showing a weak positive histochemical reaction for collagen fibers deposition in the portal triad.

chronic administration. The hepatoprotective activity included the measurement of biochemical parameters as well as liver histopathological examination. This might be considered as the first report on the in vivo hepatoprotective activity of $C$. cretica L. extracts.

Preservation of liver function after being disturbed by hepatotoxin is considered one of the major criteria for judging the quality of any hepatoprotective agent (Madhu et al., 2012). Intraperitoneal treatment with $\mathrm{CCl} 4$ was shown to induce hepatotoxicity reflected in liver dysfunction, high oxidative stress and inflammation in rats (Al-Okbi et al., 2018) and liver injury, fibrosis, and cirrhosis in mice (Peng et al. 2016). Treatment by $\mathrm{CCl} 4$ in the present work represented by $\mathrm{CCl} 4$ intoxicated control rats showed similar results as could be seen from biochemical and histopathological changes. Liver damage induced by $\mathrm{CCl} 4$ was reflected in the increase in the activity of liver function enzymes attributed to the injury of the structural integrity of the liver (hepato-cytolysis) which lead to enzymes release into the circulation. Transaminases and ALP activity and total bilirubin are common biomarkers for evaluation of liver damage. Healing of hepatic parenchyma, hepatic membrane, and regeneration of liver cells produced restoration of the normal level of such parameters (Parmar et al, 2010).

Reactive oxygen species are a major cause of oxidative stress that could lead to DNA strand breakage, gene mutation and DNA-DNA and DNA-cross (Gülçin et al., 2002b). Liver is highly sensitive to toxic agents that could induce high oxidative stress resulted from the increased production of free radicals and reduction of antioxidant defenses that leads to oxidative damage of membranes and tissue injury (Lou et al., 2003). The antioxidant defense system is divided into enzymatic like SOD, CAT, glutathione-S-transferase (GST), glutathione reductase and peroxidase, or non-enzymatic such as vitamins $\mathrm{E}$ and $\mathrm{C}$ as well as reduced glutathione. GSH directly participates in the scavenging of free radicals (Lukaszewicz and Moniuszko, 2004) and maintenance of membrane protein thiols as well as a substrate for glutathione peroxidase and GST. Catalase is present in red cell and liver and has the ability to protect the tissue from the 
highly reactive hydroxyl radicals through decomposing hydrogen peroxides (Dash et al., 2007). Reduction in the antioxidant enzymes may lead to deleterious effects due to the accumulation of superoxide radicals and hydrogen peroxide. According to the present results, reduced glutathione was significantly reduced in the liver of intoxicated control group compared to normal control. These results are agreed with the results obtained by Sahreen et al. (2011), who reported depletion of the hepatic GSH in CCl4 treated rats. Palanivel et al. (2008) observed a reduction in the GSH level along with an elevation in lipid peroxidation in rats treated by CCl4. Lipid peroxide is not only noxious to the body but also its stable product MDA could modify protein structures (Ha and Lee, 2003). The reaction between MDA and the primary amino groups of proteins forms Schiff base compounds, that produce intra and intermolecular linkages that in turn can lead to polymerization and inactivation of enzymes. In addition, MDA reactivity towards amino groups can inhibit DNA and RNA protein synthesis (Bird and Draper, 1980). ROS affects the antioxidant defense mechanisms, reduces the intracellular concentration of GSH, decrease the activity of SOD and enhances lipid peroxidation (Khan et al., 2012). It was reported that the SOD enzyme activity was inhibited in $\mathrm{CCl} 4$ treated rats that were ascribed to inactivation of the antioxidant enzymes (Mohamed et al., 2014). This may produce an accumulation of SOD that could further stimulate lipid peroxidation. In addition, the inhibition in GSH concentration can affect redox equilibrium leading to enhanced lipid peroxidation processes (Al-Olayan et al., 2014).

Reviewing available literature, both sterols and/or triterpenes were detected and identified in C. cretica L (Hussain et al., 2005) as could be seen in the present study. The presence of $\beta$-sitosterol, $\alpha$ - sitosterol, and $\beta$-amyrin could confer the antiinflammatory and antioxidant effects to the non-polar extract (petroleum ether) as previously reported (Ammar et al., 2014; Mohamed et al., 2010). Also phytol, a diterpene alcohol, which present in the petroleum ether extract was reported to possess antiinflammatory activity by reducing cytokine production, as well as an antioxidant effect through elevating GSH and reducing MDA (Islam et al., 2015; Silva et al., 2014). Hence, the presence of the aforementioned four compounds in the petroleum ether extract could elicit synergistic antioxidant and anti-inflammatory effects which confirm the effect of petroleum ether extract in the in vivo experiment. However, in the in vitro DPPH scavenging activity, the antioxidant effect of petroleum ether was only observed on a very high dose which proposes the possible production of bioactive metabolite within the body that lead to bioactivity in the body.

Plant polyphenols possess free radical scavenging activity, inhibition of peroxidation, chelation of transition metals and antioxidant activities with subsequent anti-inflammatory effect (Al-Okbi et al., 2017). Total phenolic for both ethyl acetate and ethanol extracts of C. cretica L. (21.07 and $22.95 \mathrm{mg} \mathrm{GAE} / \mathrm{g}$, respectively) were found to be higher than that reported in the study of Sunita et al. (2011) where they were 7.081 \pm 1.033 and $12.833 \pm 0.24 \mathrm{mg}$ Gallic acid equivalent/g, respectively. However, the same authors showed total flavonoid contents for both ethyl acetate and ethanol extracts $(6.664 \pm 0.985$ and $11.979 \pm 1.049 \mu \mathrm{g}$ quercetin equivalents (QRT)/g to be nearly the same as the present study (6.25 and $10.18 \mathrm{mg} \mathrm{CE} / \mathrm{g}$, respectively).
Cressa cretica L. polar extracts were shown in the present study to contain several flavonoidal and phenolic compounds (17 and 16 compounds in ethyl acetate and 70\% alcohol extracts, respectively) by HPLC analysis. To the best of our knowledge, this might be the first report on the HPLC analysis of ethyl acetate extract. These identified compounds may impart the extracts their antioxidant activity shown in both in vitro and in vivo study in the current work. It is worthy to mention that the data obtained in the in vitro antioxidant test of $C$. cretica $\mathrm{L}$. in the present study agreed with that of Sunita et al. (2011), who also examined the ethyl acetate and methanol extracts of the plant using DPPH radical scavenging activity and revealed that, ethyl acetate extract $<70 \%$ methanol extract. Cressa cretica L. was reported to be a potential source of natural antioxidants such as phenolics, flavonoids (Sunita et al., 2011), coumarins (Bahar, 1998; Rastogi and Mehrotra, 2005) and lignans (Shahat et al., 2004). The phytochemical constituents of the ethyl acetate extract of $C$. cretica $\mathrm{L}$. were illustrated by Shahat et al. (2005) and Rastogi and Mehrotra (2005) that indicated the occurrence of phenolics and flavonoidal compounds such as quercetin, quercetin-3-O-glucoside, kaempferol-3-O- glucoside, kaempferol-3-O-rhamnoglucoside and rutin in the extract which partially agreed with that detected in the present work.

The mechanism of the hepatoprotective effect of the different tested extracts in the present study could be accomplished via their antioxidant and anti-inflammatory activities that could prevent hepatic lesions induced by $\mathrm{CCl} 4$ and that can lead to improving liver function. The anti-inflammatory effect of petroleum ether was reflected in reducing hepatic NO along with reducing the oxidative stress represented by increased serum TAC and liver catalase, SOD, GSH and reduction in hepatic MDA in the current study. Prakash et al. (2001) demonstrated that GSH conjugates play an important role in eliminating CCl4-induced toxic metabolites that induce liver injury. The presence of $\mathrm{Mn}, \mathrm{Zn}$, and $\mathrm{Cu}$ in $C$. cretica $\mathrm{L}$ aerial parts as seen from the current work could enhance the enzymatic antioxidant defense mechanism of the body (Kwun et al., 2002).

Marked improvement in liver tissue architecture upon treating intoxicated rats with the successive extracts of $C$. cretica L., was observed especially the ethyl acetate extract which was efficient more or less as the reference herbal drug, silymarin, or even better and followed by $70 \%$ ethanol extract. The improvement in liver histopathology indicated the capability of the studied extracts for acceleration of liver regeneration.

Silymarin, the reference herbal drug used in the present study, is a flavonoid complex derived from Silybum marianum, the herb milk thistle with an antioxidant activity and can attenuate free radicals elevation, inhibit lipid peroxidation, chelate metal ions and prevents liver glutathione depletion (El-Hawary et al., 2011).

The use of ethyl acetate and $70 \%$ ethanol extracts of $C$. cretica $\mathrm{L}$. could protect the liver from damage by $\mathrm{CCl} 4$ as evident by the improved histological picture and biochemical markers of liver damage. The $\mathrm{CCl}_{4}$ induced hepatotoxicity produced in rats leading to hepatic injury triggers the generation of toxic radicals which can be masked by using a correct antioxidant in adequate amount which might be represented by the present tested extracts. The hepatoprotective activities of certain flavonoids are known to minimize the hemorrhage caused by $\mathrm{CCl}_{4}$ in the liver as flavonoids are known to be the vascular protector (Kummar et al., 2009). 
The present study showed the safety of petroleum ether, ethyl acetate and $70 \%$ ethanol extracts up to $3 \mathrm{~g} / \mathrm{kg}$ mice body weight. The chronic administration of the extracts as 500 $\mathrm{mg} / \mathrm{kg}$ rat body weight for 4 weeks to normal rats during the in vivo experiment showed also complete safety towards different biochemical parameters and liver tissue histology.

\section{CONCLUSION}

Petroleum ether, ethyl acetate, and 70\% ethanol extracts produced hepatoprotective effect through improvement in liver functions, liver enzymatic and non-enzymatic antioxidant, malondialdehyde and nitric oxide and serum TAC, and liver histopathology. $70 \%$ ethanol and ethyl acetate extracts were superior and comparable to silymarin and even better concerning specific biomarkers and histopathology. The hepatoprotective effect could be attributed to the presence of phenolic and flavonoidal compounds in the polar extract; $\beta$-sitosterol, $\alpha$-sitosterol, and $\beta$-amyrin in non-polar extract and the in vitro antioxidant activity of $70 \%$ ethanol extract in addition to the presence of $\mathrm{Mn}, \mathrm{Cu}$ and $\mathrm{Zn}$ trace elements that are essential to the enzymatic antioxidant defense mechanism of the body.

\section{ROLE OF FUNDING SOURCE} Centre, Egypt.

This work was financed by the National Research

\section{CONFLICT OF INTERESTS}

There are no conflicts of interest.

\section{REFERENCES}

Adams RP. Identification of essential oil components by gas chromatography mass spectroscopy. Allured Publishing Corporation, Carol Stream, IL, 1995.

Al-Okbi SY, Abdel-Razek AG, Mohammed SE, Ottai ME. Roselle seed as a potential new source of healthy edible oil. J Biol Sci, 2017; 17(6):267-77.

Al-Okbi SY, Mohamed DA, Hamed TE, Edris AE, Fouda K Hepatic regeneration and reno-protection by fish oil, Nigella sativa oil and combined fish oil/Nigella sativa volatiles in $\mathrm{CCl} 4$ treated rats. J Oleo Sci, 2018; 67(3):345-53.

Al-Olayan EM, El-Khadragy MF, Metwally DM, A bdelMoneim AE. Protective effects of pomegranate (Punica granatum) juice on testes against carbon tetrachloride intoxication in rats. BMC Complem Altern Med, 2014; 14:1-9.

Ammar NM, Hefnawy MS, Al-Okbi SY, Mohamed DA, ElSayed NK, El-Anssary AA, Mabry T. Phytochemical and biological studies of Butia capitata Becc. Leaves cultivated in Egypt. Asian Pac J Trop Biomed, 2014; 4(6):456-62.

Anguo W, Tingting D, Dan T, Youhua X, Liang F, Zhaoguang Z, Jiaxiao Z, Rushang W, Quan Z. Determination of nitric oxide-derived nitrite and nitrate in biological samples by HPLC coupled to nitrite oxidation. Chromatographia, 2013; 76:1649-55.

Bahar A. Cresoside: a new coumaranochromone glycoside from fruits of Cressa cretica Linn. Indian J Nat Prod, 1998; 14(2):29-32.

Bergmeyer H, Bernt E. Practical clinical biochemistry. 5th edition, Willian Heinmann Medical Books Ltd, London, UK, p 741, 1980.

Bird RP, Draper HH. Effect of malonaldehyde and acetaldehyde on cultured mammalian cells: growth, morphology, and synthesis of macromolecules. J Toxicol Environ Health, 1980; 6:811-23.

Boulos L. Flora of Egypt checklist. Al-Hadara Publishing, Cairo, Egypt, p 174, 2009
Bruckner J. Estimation of the direct and total bilirubin in serum investigations and observations by a modified method. Clin Chim Acta, $1961 ; 6: 370-5$.

Buege JA, Aust SD. Microsomal lipid, peroxidation. In: Flesicher S, Packer L (eds.). Methods in enzymology. Academic Press, New-York, 52, p 302-10, 1978.

Chapman HD, Pratt PT. Methods of analysis for soils, plants and water. University of California, Dept. of Agric. Sci, California, p 320, 1978.

Dash DK, Yeligar VC, Nayak SS, Ghosh T, Rajalingam R, Sengupta P, Maiti BC, Maity TK. Evaluation of hepatoprotective and antioxidant activity of Ichnocarpus frutescens (Linn.) R. Br. on paracetamolinduced hepatotoxicity in rats. Trop J Pharm Res, 2007; 6:755-65.

El-Hawary SA, Sokkar NM, Ali ZY, Yehia MM. A profile of bioactive compounds of Rumex vesicarius L. J Food Sci, 2011; 76:C1195-202.

Finar IL. Organic chemistry. 5th edition, Longmans Green and Co. Ltd, London, UK, Vol. 1, p 212, 1967.

Gülçin IU, Oktay M, Küfrevioğlu ÖI, Aslan A. Determination of antioxidant activity of lichen Cetrariaislandica (L.), Ach. J Ethnopharmacol, 2002; 79:325-9.

Ha BJ, Lee JY. The effect of chondroitin sulfate against CCl4induced hepatotoxicity. Biol Pharm Bull, 2003; 26:622-6.

Hirsch MS, Faquin WC, Krane JF. Thyroid transcription factor-1, but not $\mathrm{p} 53$, is helpful in distinguishing moderately differentiated neuroendocrine carcinoma of the larynx from medullary carcinoma of the thyroid. Mod Pathol, 2004; 17:631-6.

Hussain S, Ahmed E, Malik A, Jabbar A, Arshad M. Phytochemical studies of Cressacretica. J Chem Soc Pak, 2005; 27(3):296-8.

Islam MT, de Alencar MV, da Conceição Machado K, da Conceição Machado K, de CarvalhoMelo-Cavalcante AA, de Sousa DP, de Freitas RM. Phytol in a pharma-medico-stance. Chem Biol Interact, 2015; 240:60-73.

Khan RA, Khan MR, Sahreen S. CCl4-induced hepatotoxicity: protective effect of rutin on $\mathrm{p} 53, \mathrm{CYP} 2 \mathrm{E} 1$ and the antioxidative status in rat BMC Complem Altern Med, 2012; 8:172-8.

Kim K, Tsao R, Yang R, Cui, SW. Phenolic acid profiles and antioxidant activities of wheat bran extracts and the effect of hydrolysis conditions. Food Chem, 2006; 95(3):466-73.

Koracevic D, Koracevic G, Djordjevic V, Andrejevic S, Cosic $\mathrm{V}$. Method for the measurement of antioxidant activity in human fluids. $J$ Clinic Pathol, 2001; 54:356-61.

Kummar PV, Sivarag A, Elumalai EK, Kumar BS. Carbon tetrachloride-induced hepatotoxicity in rats-Protective role of aqueous leaf extracts of Coccinia grandis. Int J Pharm Tech Res CODEN (USA), 2009; 1(4):1612-5.

Kwun IS, Jang HS, Kwon CS. Plasma level of antioxidan minerals $(\mathrm{Cu}, \mathrm{Zn}, \mathrm{Mn}$, and $\mathrm{Se})$ and $\mathrm{Fe}$. In: Roussel $\mathrm{AM}$, Anderson RA, Favrier AE (eds.). Trace elements in man and animals. Springer, Boston, MA, 2002.

Lindsay WL, Norvell WA. Development of a DTPA micronutrient soil tests for Zinc, iron, manganese and copper. J Soil Sci Amer, 1978; 42:421-8.

Lou Z, Minter-Dykhouse $\mathrm{K}, \mathrm{Wu} \mathrm{X}$, Chen J. MDC1 is coupled to activate $\mathrm{CHK} 2$ in mammalian DNA damage response pathways. Nature, 2003; 421:957-61.

Lukaszewicz HJ, Moniuszko J. Liver catalase, glutathione peroxidase and reductase activity, reduced glutathione and hydrogen peroxide levels in acute intoxication with chlorfenvinphos, an organophosphate insecticide A. Pol J Environ Stud, 2004; 13:303-9.

Mabberley DJ. The Plant-book. CPI Group Ltd, Croydon, UK,

Macdonald HG. A dictionary of natural products. N.J.7 Plexus Publishing, Medford, p 187, 1997.

Madhu KP, Vijaya Raju A, Ganga Rao B. Investigation of hepatoprotective activity of Cyatheagigantea (Wall. ex. Hook.) leaves against paracetamol-induced hepatotoxicity in rats. Asian Pac J Trop Biomed, 2012; 2(5):352-6. 
Marsillach J, Camps J, Ferre N, Beltran R, Rul A, Mackness $\mathrm{B}$, Michael M, Jorge J. Paraoxonase-1 is related to inflammation, fibrosis and PPAR delta in experimental liver disease. BMC Gastroenterol, 2009; 9:1-13.

Mohamed NZ, Abd-Alla HI, Aly HF, Mantawy M, Ibrahim N, Hassan SA. CCl4-induced hepatonephrotoxicity: protective effect of nutraceuticals on inflammatory factors and antioxidative status in rat. J Appl Pharm Sci, 2014; 4:087-100.

Moron MS, Depierre JW, Mannervik B. Level of glutathione, glutathione reductase and glutathone-S-transferase activities in rat lung and liver. Biochem Biophys Acta, 1979; 582:67-78.

Mohamed DA, Hamed TE, Al-Okbi SY. Reduction of hypercholesterolemia and risk of cardiovascular diseases by plant foods extracts mixtures: a study on plasma lipid profile, oxidative stress and testosterone in rats. Grasas y Aceites, 2010; 61(4):378-89.

Nishikimi M, Rae NA, Yagi K. The occurrence of superoxide anion in the action of reduced phenazinemethosulphate and molecular oxygen. Biochem Biophys Res Commun, 1972; 46:849-53.

Oktay M, Gülçin I, Küfrevio I. Determination of in vitro antioxidant activity of fennel (Foeniculumvulgare) seed extracts. LebensmWiss Technol, 2003; 36:263-71.

Palanivel MG, Rajkapoor B, Kumar RS, EInstein J W, Kumar EP, Kumar MR, Kavitha K, Kumar MP, Jayakar B. Hepatoprotective and antioxidant effect of Pisoniaaculeata L. against CCl4-induced hepatic damage in rats. Sci Pharm, 2008; 76:203-15.

Parmar SR , Patel HV, Kalia K. Hepatoprotective activity of some plants extract against paracetamol induced hepatotoxicity in Wistar rats. J Herbal Med Toxicol, 2010; 4(2):101-6.

Peng WH, Chen YW, Lee MS, Chang WT, Tsai JC, Lin YCh, Lin MK. Hepatoprotective effect of Cuscutacampestris Yunck. whole plant on carbon tetrachloride induced chronic liver injury in mice. Int J Mol Sci, 2016; 17(12):2056.

Prakash J, Gupta SK, Kochupillai V, Singh N, Gupta YK, Joshi S. Chemopreventive activity of Withaniasomnifera in experimentally induced fibrosarcomatumours in swiss albino mice. Phytother Res, 2001; 15:240-4.

Priyashree S, Jha S, Pattanayak SP. A review on Cressa cretica Linn.: a halophytic plant. Pharmacogn Rev, 2010; 4(8):161-6.

Raje S, Sane RT, Mangaonkar K, Shailajan S, Pathak G, Jariwala N, Kasar D. Determination of heavy metals from Cressa cretica using atomic absorption spectroscopic technique. J Indian Chem Soc, 2006; 83(6):611-2.

Ramachandran R, Ali M. Isolation and characterization of acyclic terpenic constituents from Cressa cretica aerial parts. J Med Aromat Plant Sci, 2003; 25(1):81-90.

Rastogi RP, Mehrotra BN. Compendium of Indian medicinal plants. Central Drug Research Institute, Lucknow and National institute of science communication and information resources, New Delhi, Vol. I, p 126, 2004.

Rastogi RP, Mehrotra BN. Compendium of Indian medicinal plants. Central Drug Research Institute, Lucknow and National institute of science communication and information resources, New Delhi, Vol. III, p 254, 2005.

Reitman S, Frankel S. Colorimetric method for the determination of serum glutamic oxaloacetic and glutamic pyruvic transaminases. Am J Clin Path, 1957; 28:56-63.
Romano CS, Abadi K, Repetto V, Vojnov AA, Moreno S. Synergistic antioxidant and antibacterial activity of rosemary plus butylated derivatives. Food Chem, 2009; 115:456-61.

Sahreen S, Khan MR, Khan RA. Hepatoprotective effects of methanol extract of Carissa opaca leaves on $\mathrm{CCl}_{4}$-induced damage in rat. BMC Complem Altern Med, 2011; 11:48.

Satakopan S, Karandikar GK. Studies in the American convolvulaceae. J Sci Ind Res, 1961; 20:156.

Shahat AA, Abdel-Azim NS, Pieters L, Vlietinck AJ. Isolation and NMR spectra of syringaresinol-h-dglucoside from Cressacretica, Fitoterapia, 2004; 75(7-8):771-3.

Shahat AA, Nazif NM, Nahla AS, Luc P, Arnold VJ. Flavonoids from Cressa Cretica. Qatar Uni Sci J, 2005; 25:72-7.

Sharma RK, Siddiqi JN, Sharma B. Protective effect of Silymarin on human erythrocyte against tert-butyl hydroperoxide induced oxidative stress in vitro. Am J Biochem Mol Biol, 2012; 2:167-74.

Silva RO, Sousa FB, Damasceno SR, Carvalho NS, Silva VG, Oliveira FR, Sousa DP, Aragão KS, Barbosa AL, Freitas RM, Medeiros JV. Phytol, a diterpene alcohol, inhibits the inflammatory response by reducing cytokine production and oxidative stress. Fundam Clin Pharmacol, 2014; 28(4):455-64.

Sunita P, Jha S, Pattanayak SP. Anti-inflammatory and in-vivo antioxidant activities of Cressa cretica Linn., a Halophytic plant. MiddleEast J Sci Res, 2011; 8(1):129-40.

Täckholm V. Students' flora of Egypt. 2nd edition, Cairo University Press, Cairo, Egypt, 1974.

Thirunavukkarasu, P, Asha S, Ramanathan T, Balasubramanian T, Shanmogapriya R, Renugadevi G. In vitro hepatoprotective activity of isolated fractions of Cressa Cretica. Pharm Chem J, 2014; 48(2):121-6.

Tsuda K, Sakai K, Tanabe K, Kishida Y. Isolation of 22-dehydrocholestrol from Hypnea japonica. J Am Chem Soc, 1960; 82:1442-3.

Zilic S, Serpen A, Akillioglu G, Jankovic M, Gokmen V. Distributions of phenolic compounds, yellow pigments and oxidative enzymes in wheat grains and their relation to antioxidant capacity of bran and debranned flour. J Cereal Sci, 2012; 56:652-8.

How to cite this article:

El-Alfy TS, Ammar NM, Al-Okbi SY, Salama MM, Aly HF, Amer AA. Cressa cretica. L. growing in Egypt: Phytochemical study and potential antioxidant and hepatoprotective activities. J Appl Pharm Sci, 2019; 9(S1):046-057. 